\title{
Analysis Of Political Participation For People With Disabilities In Election 2019 (Case Study in Purwakarta District)
}

\author{
Yuannita Kartika Hermana ${ }^{1}$, Idrus Affandi ${ }^{2}$ \\ 1,2.Indonesian University of Education, Bandung. Indonesia \\ yuannita.kh@upi.edu ${ }^{1}$, idrusaffandi@upi.edu²
}

\begin{abstract}
Elections should be able to guarantee the implementation of the constitutional rights of every citizen including persons with disabilities but in reality the political participation of people with disabilities in the 2019 elections in Purwakarta has not been fully fulfilled. The study aims to determine the political participation of persons with disabilities in the 2019 elections in Purwakarta. The method used is a case study with a qualitative approach. The results of the study are still relatively low in voting or 33 percent voting and the lack of availability of data sources of persons with disabilities by the KPU, socialization in election 2019, the lack of observance of the organizers of the (KPPS ) in building access polling stations (TPS), and there are still negative framing of some voters in inequality for disability voters in using their voting rights. It can be concluded that the participation of persons with disabilities in the 2019 elections in Purwakarta district is not yet optimal.
\end{abstract}

Keywords: Democracy, Elections, Political Participation, Persons with Disabilities.,

\section{Introduction}

Elections as a means of conveying people's democratic rights. The existence of institutional elections has been recognized by countries based on popular sovereignty. Problems in the general election which are always questioned in the practice of citizenship, namely regarding the teachings of people's sovereignty and understanding democracy. Where democracy as an embodiment of popular sovereignty and elections is a reflection of democracy. The general election is also one of the most principal means of channeling the rights of citizens. Therefore, in the context of implementing the rights of citizens, it is the government's obligation to guarantee the implementation of the human rights of citizens in conducting elections in accordance with the principle of popular sovereignty in which the people are sovereign, then all aspects of organizing the general election itself must also be returned to the people to determine it. Is a violation of human rights if the government does not guarantee the implementation of general elections properly. Citizens' rights in which every citizen has the right to participate and participate in giving their voting rights in elections. According to Almond in the book Comparison of the political system, [1], that the factors that influence one's active participation in political participation are shown, among others: Higher education, socio-economic status, membership in political parties and how a lot of participation in the political process. While Ramlan Surbakti the factor which is estimated to influence the level of one's political participation is political awareness and trust in the government (political system). What is meant by political awareness is awareness of the rights and obligations as citizens. This concerns one's knowledge of the social and political 
environment, and concerns one's interest and attention to the social and political environment in which he lives. What is meant by attitudes and trust in government is a person's assessment of the government: whether he assesses can be trusted and can be influenced or not [2]

Regarding political rights for persons with disabilities in Indonesia, it is still a serious problem, where there is often discrimination in the implementation of fulfilling political rights for persons with disabilities. People with disabilities often experience discrimination and unequal treatment. Previous studies have shown that disability generally suppresses political participation [3] And until now it has been felt that persons with disabilities have not yet had the maximum opportunity to participate in politics and government, this is evidenced by the still low political participation of persons with disabilities in voting in elections. Persons with disabilities still face obstacles in the public domain or all aspects of the policy making process, continue to be marginalized and discriminated against in basic areas such as public accessibility and transportation, participation in community or environmental activities, all of these represent aspects that contribute to the delay in their full involvement in social and civil participation [4]. In studies show that people with hearing impairment experience barriers to participation in communication, mobility, functions of daily life, and social interaction [5].

The importance of political participation of persons with disabilities in the holding of elections is the implementation of the political rights of persons with disabilities who have the same position as other voters. This relates to participatory civic skills or participatory skills possessed by Indonesian citizens. In this case it means that people with disabilities have the right to have the skills to influence the running of government, public decision making, coalition, managing conflicts and so on. Then the election should also give special attention to them. One way is to provide space for all suffrage holders including persons with disabilities with access elections. When elections are seen as a form of political participation, then a perception will greatly affect the attitudes, behavior and motivation to continue to always play an active role in the upcoming elections. Inequality and disparity with persons with disabilities raises their own perceptions of the conduct of elections. The perspective on these problems tends not to bring solutions, especially for persons with disabilities, can even affect their attitudes towards the democratic process. Problems will arise when this perspective produces apathy towards elections and develops in persons with disabilities. This condition is certainly not something that is desired in the democratic process.

Based on the description above, the purpose of this research is to find out the political participation of persons with disabilities in the 2019 elections in Purwakarta district. As well as identifying several factors that influence this.

\section{Method}

The research approach used in this study is a qualitative approach, in which the researcher tries to dig up as much information as possible about the problem which is the research topic by prioritizing verbal data Looking at the characteristics of the problem being studied, this research was conducted using the case study method. Cresswell's Opinion in Qualitative Inquiry and Research Design: Choosing Among Five Traditions. Reveal that the focus of the case study is the case specification in an event that includes an individual, a cultural group or a portrait of life. Furthermore Cresswell [6] suggests several characteristics of a case study, namely: (1) identifying the "case" of a study; (2), the case is a "system related" by time and place; (3), case studies use various sources of information in gathering data to provide a 
detailed and in-depth description of the response of an event and (4) use a case study approach,

To determine the technique of obtaining clear and quality informants in answering the problems of this study, the researchers used purposeful sampling and snowball sampling techniques. Patton purposeful sampling, that is, researchers intentionally choose individuals and places to study or understand central phenomena [7]. Creswell, the standard used in selecting participants and places is whether they are rich in information [8]. The research subjects to obtain data in this study are: people with disabilities, Purwakarta Regency Election Commission (KPUD), persons with disabilities, Purwakarta district government. Data collection techniques using observation, interviews and documentation studies which are then analyzed and presented through descriptions,

\section{Results and Discussion}

\subsection{Results}

The process of simultaneous general elections in 2019 which was held in Purwakarta district had been carried out successfully and safely. The success of the Purwakarta regency election, one of which is determined by how the residents of Purwakarta regency carry out political participation in the simultaneous general election activities in Purwakarta district, except for persons with disabilities.

In order to find out the participation of voters with disabilities in Purwakarta regency in six constituencies in voting in the 2019 general election, it can be seen from the following table:

Table 1. the participation of voters with disabilities

\begin{tabular}{|c|c|c|c|c|c|c|c|c|c|c|c|}
\hline \multicolumn{12}{|c|}{ SELECTION OF DISABILITIES WITH USERS OF SELECT RIGHTS } \\
\hline \multicolumn{12}{|c|}{ IN ELECTION PILPRES IN 2019} \\
\hline \multirow{2}{*}{ No } & \multirow{2}{*}{ Dapil } & \multirow{2}{*}{ Kecamatan } & \multicolumn{2}{|c|}{ Chooser } & \multirow[b]{2}{*}{ Total } & \multicolumn{3}{|c|}{ User Voter Rights } & \multicolumn{3}{|c|}{$\begin{array}{c}\text { Participation Level } \\
(\%)\end{array}$} \\
\hline & & & $\mathrm{M}$ & $\mathrm{F}$ & & M & $\mathrm{F}$ & Total & M & $\mathrm{F}$ & Total \\
\hline 1 & 1 & Purwakarta & 40 & 36 & 76 & 34 & 27 & 61 & $85 \%$ & $75 \%$ & $80 \%$ \\
\hline 2 & 2 & Babakan Cikao & 20 & 26 & 56 & 21 & 16 & 37 & $105 \%$ & $62 \%$ & $66 \%$ \\
\hline 3 & 2 & Bungur Sari & 35 & 38 & 73 & 13 & 19 & 32 & $37 \%$ & $50 \%$ & $44 \%$ \\
\hline 4 & 2 & Campaka & 23 & 25 & 48 & 13 & 14 & 27 & $57 \%$ & $56 \%$ & $56 \%$ \\
\hline 5 & 2 & Cibatu & 5 & 13 & 18 & 5 & 13 & 18 & $100 \%$ & $100 \%$ & $100 \%$ \\
\hline 6 & 3 & Pasawahan & 36 & 22 & 58 & 12 & 9 & 21 & $33 \%$ & $41 \%$ & $36 \%$ \\
\hline 7 & 3 & Pondoksalam & 7 & 5 & 12 & 4 & 4 & 8 & $57 \%$ & $80 \%$ & $67 \%$ \\
\hline 8 & 3 & Kiarapedes & 24 & 23 & 47 & 5 & 4 & 9 & $21 \%$ & $17 \%$ & $19 \%$ \\
\hline 9 & 3 & Wanayasa & 16 & 27 & 43 & 4 & 4 & 8 & $25 \%$ & $15 \%$ & $19 \%$ \\
\hline 10 & 4 & Darngdan & 43 & 35 & 78 & 10 & 8 & 18 & $23 \%$ & $23 \%$ & $23 \%$ \\
\hline 11 & 4 & Bojong & 19 & 15 & 34 & 4 & 3 & 7 & $21 \%$ & $20 \%$ & $21 \%$ \\
\hline 12 & 5 & Plered & 12 & 6 & 18 & 8 & 4 & 12 & $67 \%$ & $67 \%$ & $67 \%$ \\
\hline 13 & 5 & Maniis & 17 & 16 & 33 & 6 & 2 & 8 & $35 \%$ & $13 \%$ & $24 \%$ \\
\hline 14 & 5 & Tegal Waru & 10 & 12 & 22 & 3 & 4 & 7 & $30 \%$ & $33 \%$ & $32 \%$ \\
\hline 15 & 6 & Jatiluhur & 134 & 108 & 242 & 7 & 2 & 9 & $5 \%$ & $2 \%$ & $4 \%$ \\
\hline 16 & 6 & Sukatani & 23 & 24 & 47 & 9 & 9 & 18 & $39 \%$ & $38 \%$ & $38 \%$ \\
\hline \multirow[t]{2}{*}{17} & 6 & Sukasari & 2 & 3 & 5 & 2 & 0 & 2 & $100 \%$ & $0 \%$ & $40 \%$ \\
\hline & & & 466 & 434 & 910 & 160 & 142 & 302 & $34 \%$ & $33 \%$ & $33 \%$ \\
\hline
\end{tabular}


Based on data from the Regional Election Commission (KPUD) of Purwakarta regency, information was obtained that the list of Permanent Voters (DPT) in the Purwakarta Regency in the six electoral regions was 910 people. However, after voting was done, there were 302 people with disabilities who used their right to vote in the 2019 elections or $33 \%$ participation rate. These results illustrate that the political participation of voters with disabilities in Purwakarta district in the 2019 elections is very low.

Even though the disability participation category in Purwakarta district is low, but in several districts namely Purwakarta, Babakan Cikao, Campaka, Pondok salam and Plered the level of political participation is above 50 percent. even in Cibatu sub-district the participation rate is 100 percent. Participation figures in five districts show that voters with disabilities in five districts namely Purwakarta, Babakan Cikao, Campaka, Pondok salam and Plered have a good level of political awareness and in Cibatu sub-district are very good.

Factors Influencing Participation of Persons with Disabilities in the 2019 Elections (1) Data Collection. One of the factors causing the high and low participation of persons with disabilities during the elections, including data collection. During this time, the data collection conducted by officers to persons with disabilities encountered many difficulties because the officers did not understand the condition of persons with disabilities. In Purwakarta regency the KPUD has collaborated with various parties such as the Social Service, Disdukcapil and Disabled Persons Organizations. KPUD Purwakarta Regency works closely with the Social Service and Disdukcapil Purwakarta Regency to find a database of persons with disabilities in Purwakarta Regency. Because it is aware that up to now the database of persons with disabilities has become an obstacle to the political participation of persons with disabilities in Purwakarta Regency. This happens because it is not uncommon for families with disability family members to not be open to the presence of their members or even assume that individuals with disabilities do not need to be involved in activities like ordinary people. As well as the collaboration carried out by the Purwakarta District Election Commission in terms of cross-checking the number of persons with disabilities who have been able to vote in the 2019 elections in Purwakarta Regency. With the aim, if there are persons with disabilities who have not been registered as voters, they can register themselves immediately. (2) 2019 Election Socialization. KPUD of Purwakarta Regency as the organizer has conducted election socialization to persons with disabilities. Where during the socialization, the Purwakarta KPUD appealed to persons with disabilities to use their voting rights on the voting day and gave a lot of debriefing, especially how to vote correctly. Not escape, the presentation of sample ballot templates for blind voters. More than that, to increase the political participation of persons with disabilities in Purwakarta district. But still, voters with disabilities feel confusion and accompanying officers who appear to be confused about handling voters with special needs. (3) Facilities and Accessibility. In this study, facilities were operated on aids in TPS. The results of the research in the field there are respondents who expressed dissatisfaction in organizing the 2019 elections in Purwakarta Regency. Based on the findings of the researchers in the field, there were respondents who stated that "there were only 2 ballots using temple braile from the five ballots given. Three ballots, namely the Central DPRD election ballot, the provincial DPRD election ballot and the Regency DPRD ballot election do not use temple braile ". Accessibility where the lack of observance of the organizers of the polling group organizers (KPPS) in building polling stations (TPS) there are still difficulties in reaching access for people with disabilities. (4) Negative framing of the public from a part of the voting community at the TPS towards disability voters as a result there is still inequality for disability voters in exercising their voting rights. 


\subsection{Discussion}

Persons with disabilities are groups of people who have limitations whose limitations hamper participation and their role in community life. In the context of elections, persons with disabilities require special attention from the election organizers, namely the regional election commission (KPUD). As the organizer, the Election Commission must be able to provide facilities and facilities for people especially people with disabilities to be able to participate in political activities. One form of participation of persons with disabilities in political activities is by participating in voting during elections by coming to the polls in 2019 .

In order to achieve the fulfillment of the rights of persons with disabilities, progress has been carried out by the Indonesian government starting from the birth of Law No. 4 of 1997 concerning Disabled Persons, then over time Indonesia also ratified the Convention on the Rights of Persons with Disabilities (Conventional On the Right) Of Person With Disabilities) through Law Number 19 of 2011[9] and the latest is the birth of Law Number 8 of 2016 concerning Persons with Disabilities. These developments provide more space and guarantees for the fulfillment of the rights of persons with disabilities for the achievement of justice and improve the welfare of persons with disabilities.[10]

In Act No. 8 of 2016 concerning Persons with Disabilities states that political rights for persons with disabilities include the right to vote and be elected in public office; channel political aspirations both written and oral; elect political parties or individuals who are participants in general elections; form and become members or management of community organizations or political parties; establish and join disability organization to actively represent at the local and international level; active role inelectoral system; obtain accessibility to the facilities and infrastructure of general elections and obtain political education.

In this modern era, the government is trying to equalize people with disabilities with the general public. One of the fundamental things done by the government is to issue Law of the Republic of Indonesia Number. 19 of 2011 containing the ratification of the Convention on the Rights of Persons with Disabilities (CRPD) or the convention on the rights of persons with disabilities [11]. It was explained in it that the state's obligation to guarantee the participation of persons with disabilities in aspects of life, including politics. International treaties, such as the United Nations Convention on the Rights of Persons with Disabilities (CRPD), protect the human rights of persons with disabilities. The CRPD stipulates that women and men with disabilities have the right to vote, run for office and participate in political life on an equal footing with other citizens [12]. The Convention On The Right Of Persons With Disabilities (CRPD), in the election contest, stipulates that the government must provide accessible and easy facilities for persons with disabilities to vote without being intimidated.

Based on the research findings, the researcher believes that several factors that influence the low political participation of persons with disabilities are first, Data Collection. One of the factors that caused the high and low participation of persons with disabilities during the 2019 elections. Secondly, the Socialization of the 2019 Election. The Purwakarta District Election Commission as the organizer had conducted election socialization to persons with disabilities. Third, Facilities and Accessibility. In this study, facilities were operationalized on assistive devices at polling stations and accessibility had difficulty in accessing for persons with disabilities. Fourth negative framing of the public from some of the voters in the polling station against disability voters as a result there are still inequalities for disability voters in exercising their voting rights. 


\section{Conclusions}

Based on the results of research conducted by researchers there are several conclusions that can be described as follows: First, the level of political participation of persons with disabilities in the 2019 elections in Purwakarta district showed low results. This can be seen from the sampling of the 3 constituencies studied that only reached $35.54 \%$ of the voting rights fulfilled in the electoral process which should have been the highest political right they have as citizens of the Indonesian republic. This must then be a concern for further how political participation of persons with disabilities will increase. Secondly, several factors that influence the low political participation of persons with disabilities are Data Collection, Socialization of the 2019 General Elections, facilities and accessibility as well as negative framing from the community to people with disabilities. To increase the level of disability voter participation, several strategies need to be done including improving the data of persons with disabilities in related government agencies such as Disdukcapil and Social Affairs. Conducting special socialization for disabled voters increases the political education of disabled voters and improves the services of special KPPS officers with disabilities. Make TPS affordable access for disabled voters by being strengthened by the existence of special rules for building TPS access. And provide guidance to the wider community that people with disabilities have the same rights.

\section{Acknowledgments}

Thank you conveyed to all parties involved in writing this article. And thanks for the amount submitted to informants and information who are willing to assist researchers in completing this study.

\section{References}

[1] Mochtar, M \& Andrews, M.: Perbandingan Sistem Politik. Yogyakarta: Gajah Mada University Press. (2008)

[2] Surbakti, R. : Memahami Ilmu Politik. Jakarta: PT. Grasindo.(2007)

[3] Mattila, M., \& Papageorgiou, A.: Disability, perceived discrimination and political participation. International Political Science Review, 38(5), 505-519.doi:10.1177/0192512116655813 (2016).

[4] Iconaru, E. I., \& Ciucurel, C.: Developing Social and Civic Competencies in People with Intellectual Disabilities from a Family Center through an Adapted Training Module. Procedia Social and Behavioral Sciences, 116, 3303 3307. doi:10.1016/j.sbspro.2014.01.752 (2014).

[5] Jaiswal, A., Aldersey, H., Wittich, W., Mirza, M., \& Finlayson, M.: Using the ICF to examine contextual factors that influence participation of people with deafblindness in India. Archives of Physical Medicine and Rehabilitation .doi:10.1016/j.apmr.2019.03.010 (2019).

[6] Creswell, J. W:. Qualitative Inquiry and Research Design: Choosing Among Five Tradition. London: SAGE Publication, Inc. (1998).

[7] Patton, M, Q. ;. Qualitative Research and Evaluation Methods. USA: SAGE Publications Inc.. (2002)

[8] Creswell, J. W.: Penelitian Kualitatif \& Desain Riset. Yogyakarta : Pustaka Pelajar.. (2015)

[9] Undang- Undang RI No. 19 Tahun 2011 Tentang Pengesahan Convention On The Right Of Person With Disabilities ( Konvensi mengenai Hak-hak Penyandang Disabilitas ). 
[10] Undang- Undang RI No. 8 Tahun 2016 Tentang Penyandang Disabilitas.

[11] Undang- Undang RI No. 19 Tahun 2011 Tentang Pengesahan Convention On The Right Of Person With Disabilities ( Konvensi mengenai Hak-hak Penyandang Disabilitas ).

[12] Atkinson, V., Aaberg, R., \& Darnolf, S. :Disability Rights and Election Observation: Increasing Access to the Political Process. Nordic Journal of Human Rights, 35(4), 375-391. doi:10.1080/18918131.2017.1400348 (2017). 